\title{
TOWARDS ACHIEVING THE SUSTAINABLE DEVELOPMENT GOALS BY MICROALGAE-LIVESTOCK SYSTEMS INTEGRATION: A REVIEW
}

\author{
Aminu Bature $^{1^{*}}$, Lynsey Melville $^{2 * *}$ and Khondokar Mizanur Rahman ${ }^{2 * * *}$ \\ ${ }^{1}$ Birmingham City University and PTDF Nigeria \\ ${ }^{2}$ Birmingham City University
}

Emails:*Aminu.Bature@mail.bcu.ac.uk

**Lynsey.Melville@bcu.ac.uk

***Khondokar.Rahman@bcu.ac.uk

\begin{abstract}
By reviewing the literatures on the interrelationships between livestock agriculture and sustainable development in developing countries, this paper aims to explore how adapting and modifying livestock systems management with alga-culture can contribute to the United Nations (UN) Sustainable Development Goals (SDGs). Specific objectives were to perform an in-depth analysis of relevant interdisciplinary literature using Strengths, weaknesses, opportunities and threats (SWOT) framework to identify knowledge gaps, and isolate sections of opportunities and uncertainties that could shed light into areas that require further research. This is then followed by a quid pro quo synthetization of areas of linkage between livestock and microalgae cultivation using the SDGs as a unifying platform. The review identifies where integrated microalgae-livestock systems inclusion may have direct impact on achieving the SDGs targets such as clean water and sanitation $\left(\mathrm{SDG}_{6}\right)$, hunger and malnutrition $\left(\mathrm{SDG}_{2}\right)$, climate change $\left(\mathrm{SDG}_{13}\right)$, responsible consumption and production $\left(\mathrm{SDG}_{12}\right)$, and life on land $\left(\mathrm{SDG}_{15}\right)$. Moreover, from the perspective of the SDGs, this paper highlights that, integrated microalgae-livestock systems inclusion in the achievement of SDGs is about minimizing greenhouse gases (GHG) emissions due to livestock waste, wastewater treatment and recycling, improving nutrition, and promoting sustainable agriculture to achieve food security to meet the increasing demand for animal sourced products. Furthermore, despite conflicting evidence about the efficiency of using microalgae for animal feed supplementation, a comparative examination of the literatures on microalgae-based feedstock with conventional feeds suggest that, poor growth, health, fertility and productivity issues in farm animals due to low nutrition and poor digestibility can be improved through optimum feed supplementation using microalgae.
\end{abstract}

Keywords: Livestock Feeds, Sustainable Development Goals, Microalgae, Aquaculture

\section{Introduction}

Historically, small number of issues have enticed the attention of nations as poverty, inequality and climate change. The Sustainable Development Goals (SDGs) of the United Nations (UN) set out 17 comprehensive aspirational objectives associated with 169 targets to serve and charts the way for human development over the next 15 years (starting from 2015) generating extensive literatures of both secondary and primary nature (UNDP, 2015). Been one of the main undertakings in which the poor depends on for their livelihood, agriculture (both crop and animal sub-sectors) plays an important role in the economic development of developing countries (Kamuanga, et al., 2008; Cervantes-Godoy \& Dewbre, 2010; World Bank, 2013; FAO, 2016). The sector occupies approximately $30 \%$ of the world's terrestrial land area, employing a minimum of 1.3 billion people worldwide and directly supports 600million rural farmers in developing countries (Thornton, 2010; Iqubal, 2013; Herrero, et al., 2013; Okello, et al., 2015).A considerable amount of literature has been published confirming the increasing demand for animal sourced products due to increasing population, urbanization, and improving standard of living in developing countries (Delgado, et al., 2008; Pica-Ciamarra \& Otte, 2009; FAO, 
2009; Pica-Ciamarra \& Otte, 2009; Thornton, 2010; The World Bank, 2012).With meat production increasing from 45 to 134 million tons between the year 1980 and 2002 in developing countries, and account for 53\% of agricultural GDP in industrialized economies (The World Bank, 2009), the demand and consumption of livestock sourced products is rising faster than the human population (Orheruata\&Omoyakhi, 2008). Anecdotally, this increase in demand should ipso facto means more matching supply opportunities (Whelan, et al., 2001) for farmers to boost their income by producing more livestock products to match the high demand, and thus contribute to the SDG objective of ending poverty. However, this has led to increasing amount of animal waste that is becoming a serious problem for the environment (Shimura \&Tabuchi, 1994; Sansoucy, 1995; National Research Council, 2002; O'mara, 2011;Mekonnen\& Hoekstra, 2012) and public health (IFAH, 2012). The correlation between rapid increases in livestock production and the quantity of left over animal waste has received considerable attention (Martin \&Madewell, 1971; Bouwman\& Van Der Hoek, 1997; Thu, et al., 2012; Zhu \&Hiltunen, 2016). Previous studies into farm animal's water footprint and the concentration of nitrogen in stream water have been consistent (Shimura \&Tabuchi, 1994; Mekonnen\& Hoekstra, 2012). Livestock agriculture is responsible for 8-10\% of global GHG emissions (O’Mara, 2011) and is expected to increase pari passu with increase in food demand and world population.

These call for the development of an innovative and sustainable livestock production systems that could minimize the environmental impact of livestock agriculture as well as improve feed quality for better animal performance (National Research Council, 2002). However, to achieve these, it is important to consider the interaction between those interdisciplinary aspects that constitute sustainability in agriculture such as environmental, social, cultural and economic dimensions (Veisi, et al., 2013). Studies have shown that agriculture is one of the leading contributor to climate change (Shimura \&Tabuchi, 1994; Sansoucy, 1995;Niggli, et al., 2008; Paul, et al., 2009; Schaffnit-Chatterjee, et al., 2011,) and emission of greenhouse gases (GHG) (National Research Council, 2002;Pelletier \& Tyedmers , 2010;O’Mara, 2011; Mekonnen\& Hoekstra, 2012). This change in climate is an important component in the environmental threats facing mankind, and plays a key role in agricultural production in developing countries (Ziervogel, et al., 2006). Over the years, an enormous amount of research has been carried out investigating the impacts of livestock agriculture and animal feeding operations (AFOs) on the environment and human health (Shimura \& Tabuchi, 1994; Sansoucy, 1995; National Research Council, 2002; Mekonnen \& Hoekstra, 2012). According to Sansoucy (1995), achieving sustainable agricultural development in developing countries requires the improvement of livestock farming system efficiency. Moreover, air emission from AFOs depends on the nutrients input, management of feeding operations, manure handling practices etc. (National Research Council, 2002). While a number of researchers focused on the formation of quality feeds for the improvement of livestock productivity and performance to meet the increasing demand for animal products (Birthal \& Jha, 2005; Thornton, 2010). Others emphasized the environmental impacts that large scale livestock production have on climate change and the emission of GHGs (Shimura \& Tabuchi, 1994; Sansoucy, 1995; National Research Council, 2002; Mekonnen \& Hoekstra, 2012). Despite extensive studies carried out by both group of researchers, no single study seeks to identify solution that integrates both environmental impacts and low nutrition in livestock feeds. Therefore, it is of crucial importance to identify new livestock feed sources with high nutritional contents, better digestibility and cultivation efficacy for environmentally friendly livestock production (Poppi, \& McLennan,, 2010; Holman \& Malau-Aduli, 2013). Certainly, there are other potential ways to resolving these problems, however, this review has taken the position to investigate one solution (Alga-culture) that has attracted tens and hundreds of millions of dollars' in public money and private sector investments respectively (Barnosky, 2014). This paper will examine possible applications of microalgae in animal production.

\section{Material and Methods}

The results of this study were based upon the available secondary data collected from 102 related journals and other publications cited throughout this paper. The data was analysed using SWOT analysis 
framework(Ommani, 2011) to identify the strengths and weaknesses, as well as the opportunities and threats/uncertainties within the multidisciplinary literatures of microalgae culture and livestock agriculture that could influence strategic decision making vis-à-vis the diversification of microalgae culture into the animal feed market in developing countries and the SDGs. This study employed a modified version of the SWOT matrix(Pahl\& Richter, 2009) to identify the areas of strengths and weaknesses of the livestock sector and to forecast areas of market opportunities and uncertainties for microalgae-based feeds using the SDGs as a unifying platform.

\section{A Brief Description of Microalgae (Algae)}

In this paper the term microalgae was used interchangeably when referring to any subgroup of algae. According to Kovacevic and Wesseler microalgae can be defined as "a diverse group of microscopic organisms that inhabit marine and freshwater habitats and have the capability of photosynthesis" (Kovacevic \& Wesseler, 2010). Algae are very diverse group of organisms that constituted the lower phylogenetic echelons of the plant kingdom (Radmer, 1996). Kirst and Wiencke (1995) saw algae as a large group of photosynthetic aquatic organisms capable of producing organic materials, which are abundant in nature and grow in various climates and geographical locations including polar areas. Chisti (2007), eclectically defined microalgae as "sunlight-driven cell factories that convert carbon dioxide to potential biofuels, foods, feeds and high-value bio-actives". Moreover, algae has been refer to as autotrophic organisms which can potentially be a source of feed and food for animals and human beings (Chowdhury, et al., 1995). It has also been referred to as a "heterogeneous assemblage of organisms that range in size from tiny cells to giant seaweeds, thus algae mostly are photosynthetic species which includes eukaryotes and prokaryotic Cyanobacteria (blue-green algae) and live in aquatic habitats" (Yaakob, et al., 2014). While a variety of definitions of the term microalgae and/or algae (depending on the size) have been suggested, this paper will use the definition suggested by Mostafa et al(2012) who view it as a "photosynthetic microorganisms that are able to rapidly generate biomass from solar energy, $\mathrm{CO}_{2}$ and nutrients in bodies of water". Thus for the purpose of this study, we are looking at microalgae in terms of both its rapid (30 times faster than terrestrial oilseed crops) (Sheehan, et al., 1998) photosynthetic biomass generation that consist of vital primary metabolites like lipids, oil, sugar etc., and it utilization of $\mathrm{CO}_{2}$ as well as inorganic nutrients present in wastewater bodies.

\section{Environmental Impacts of Traditional Agricultural Practices}

Traditionally, animal waste management usually involves waste combusting for energy generation, composting for agriculture, and conversion for bioenergy (Zhu \& Hiltunen, 2016). Unfortunately, these methods usually involved some sort of emission (e.g. $\mathrm{CO}_{2}, \mathrm{CH}_{4}, \mathrm{~N}_{2} \mathrm{O}$ etc.) which are harmful to the environment and/or cause energy loss (not efficient) (Cantrell, et al., 2008). Therefore it is extremely important to seek for innovative and efficient ways to manage livestock waste.

Another environmental implication of livestock rearing raised by researchers is deforestation due to traditional farming practices such as overgrazing. According to Van Kooten and Bulte (2000), deforestation is said to occur whenever forest land is converted to an alternate permanent non-forest land e.g. use for agriculture or urban development. Deforestation due to inefficient and/or unsustainable livestock practices (e.g. overgrazing) in developing countries has been an area of concern for many researchers (Mainardi, 1998; Fearnside, 2005; Morton, et al., 2006; Wassenaar, et al., 2007). According to Fearnside, the impact of deforestation include but are not limited to; changes in hydrological regimes, loss of biodiversity, and climate change (Fearnside, 2005). In China for instance, large areas of the Qinghai province have turned into desert as a result of overgrazing (Chakravarty, et al., 2012). Cultivation of microalgae can potentially contribute to the amount of on-farm (stockpiled) feeds which in turn reduce the number of free-grazing and allow plants to recover from previous grazing, thus providing a sustainable way towards protecting and restoring terrestrial ecosystems (i.e. $\mathrm{SDGs}_{15}$ ). 
This is possible due to the fact that microalgae culture can be done year round free of seasonal constraints (Sahoo \& Seckbach, 2015).

Notwithstanding the environmental and public health concerns, the role played by agriculture in the socioeconomic development of low income countries has been advocated by numerous researchers (Johnston \& Mellor, 1961; Adelman, 1984; Vogel, 1994; Timmer, 2002; Kamuanga, et al., 2008) Increasing productivity in agriculture (both crop and animal) could contribute to both the capital and labour of other sectors of the economy (Aleksandrova, et al., 2016). In the same vein, through production and consumption linkages, agriculture can provide for urban demand inputs as well as increase rural income (Dethier \& Effenberger, 2012), thus could contributing to the achievement of the $\mathrm{SDG}_{1} \& 8$ (i.e. "end poverty in all its form everywhere" \& "Promote sustained, inclusive and sustainable economic growth, full and productive employment and decent work for all") (UNDP, 2015).

\section{The Environmental and Nutritive Value of Microalgae Integrated Animal Farming Systems}

The limitation on practical application of animal waste compost suggests the need for preliminary studies into the optimization and amplification of alga-culture with animal waste compost. Although numerous research has been carried out on potential utilization of microalgae biomass as feedstock for bioenergy (Chisti, 2007; Campbell, 2008; Hossain, et al., 2008; Hannon, et al., 2010; Singh \& Gu, 2010; Mostafa, et al., 2012), few studies have investigated the role of integrating microalgae into animal farming systems for both environmental and nutrition purposes (Phang, 1991; Spolaore, et al., 2006; Habib, et al., 2008). Increases in livestock production in the past have been mostly due to numeric growth of flocks and herds instead of to productivity improvement (Jahnke \& Jahnke, 1982) such as meeting the nutritional needs of farm animals' vis-à-vis protein, minerals and vitamins (Thornton, 2010). As noted by the Food and Agricultural Organization (FAO), the right amount of protein in animals is essential not only for animal performance, but also to decrease nitrogen emission in excreta and reduce pollution (FAO, 2002). Moreover, animal feed manufacturing and processing as well as ruminant's enteric fermentation constitute two of the main sources of emissions, representing $45 \%$ and $39 \%$ of the earth's livestock agriculture emissions, respectively. $10 \%$ of emissions is represented by the storage and processing of manure, the rest being attributable to processing and transportation of livestock products (FAO, 2013).

Microalgae requires copious amount of inorganic nutrients such as nitrogen and phosphorus to grow, which are commonly found in animal waste (Schneider, 2006). It possess the ability to efficiently utilize carbon dioxide $\mathrm{CO}_{2}$ (a potent greenhouse gas) 10 times greater compared to terrestrial plants (Miao \&Wu, 2006). Moreover, wastewater treatment and recycling concepts in aquaculture has also received a lot of attention over the past few decades (Hammouda, et al., 1995; Muller-Feuga, 2000; Guedes \& Malcata, 2012). According to Zhu and Hiltunen (2016), microalgae cultivation in animal waste (water) is potentially a sustainable way of alleviating the environmental hazard and substantial operational costs of livestock agriculture and alga-culture respectively. Furthermore, Gendy and El-Temtamy commenting on capital rationing of microalgae multiple co-products to develop pathways for technological maturity of alga-culture also uphold this view (Gendy \& El-Temtamy, 2013). There is a unique opportunity here to both reduce the impact of (animal) waste and provide nutrients to microalgae in nutrient rich (animal) wastewater (Abdel-Raouf, et al., 2012) by integrating and modifying livestock systems to manage reactive Nitrogen $(\mathrm{N})$ more efficiently (Janzen, 2011). Moreover, in the process of growth, microalgae recycle $\mathrm{CO}_{2}$ Phosphorus and inorganic nitrogen given out $\mathrm{O}_{2}$ as a by-product (Benemann \& Oswald, 1996; Abdel-Raouf, et al., 2012). Thus, can contribute to action against climate change and its impacts (i.e. $\mathrm{SDG}_{13}$ ). According to the FAO, a successful integration of the farming systems should be waste-free with no undesired by-products; as by-products of one sub-system (animal waste) is used by another sub-system (algaculture) and vice versa, generating useful materials and gases like protein biomass and $\mathrm{O}_{2}$ in the process (Phang, 1991). 


\section{Microalgae in Animal Nutrition}

According to a report by the FAO, sources of protein in feeds are numerous and diverse, with extensive opportunities for further substitutions as well as diversification and thus suggests more research on alternative sources (such as algae) before many of the opportunities can be exploited in actuality (FAO, 2002). Traditionally, ancient cultures such as the Mayas, Aztecs, Kanembu of Lake Chad and Toltecs consume nutrient rich spirulina (microalgae) as food (Moorhead \& Cysewski, 2011). Spirulina according to the FAO are multicellular and filamentous form of blue-green microalgae that belong to two distinct genera namely; Spirulina and Arthrospira, and comprises of about fifteen different species (Habib, et al., 2008). Microalgae are compost mainly of carbohydrates, proteins (50\%-70\%), lipids and trace nutrients like antioxidants, vitamins and minerals (Edwards, 2008; Yaakob, et al., 2014). These composition along with the exceptional rapid yield and digestibility aroused commercial interest in cultivating microalgae as a solution for the simple production of a good quality feed and food supplements (Chowdhury, et al., 1995; Habib, et al., 2008). Previous studies have reported that, conventional animal feeds (mostly natural pastures and crop residues) are seasonal, and have low nutritive value for ruminants and little or no feed-value for non-ruminants (Owen \& Jayasuriya, 1989; Simbaya, 2002). Moreover, studies have also shown that, fodder feeds usually contains polyphenolic compounds such as tannins and other types of anti-nutrients that affects animal digestibility and can lead to poor growth, health and low fertility in animals (D'mello, 1992; Meissner \& Paulsmeier, 1995; Leng \& Fujita, 1997; Simbaya, 2002; Vitti, et al., 2005). Polysaccharides in the cell wall of microalgae has a digestibility of $86 \%$ (with the exception brown algae) and can easily be absorbed by animals (Habib, et al., 2008; MišurCoVá, et al., 2010). Protein supplement in livestock feeds, poultry, and fish commercial diets such as feed meal, soybean and groundnut meal could be partially replaced on an isonitrogenous and isolipidic bases with microalgae (Britz, 1996; Kim, et al., 2013; Velasquez, et al., 2016). Consequently, researchers are now focusing on cultivating microalgae as a source of supplement in animal diets (Hemaiswarya, et al., 2011; Holman \& Malau- Aduli, 2013; Yaakob, et al., 2014). Previous studies have indicated that, the nutritional value of microalgae based biomass is very close to those of higher foliage, exhibiting autotrophy (mostly photoautotrophic) and heterotrophy (Becker, 1994). In addition, microalgae protein supplementation in livestock and poultry feeds does not require the addition of other vitamins and minerals such as vitamin B12, beta-carotene and cryptoxanthin (Falquet \& Hurni, 1997) as it is already contains these nutrients (Habib, et al., 2008).

There have been studies on the effects of supplementing microalgae (spirulina) in feed, advocating it credibility as a potential feedstock for livestock feeds (Al-Batshan, et al., 2001; Christaki, et al., 2012; Holman \& Malau- Aduli, 2013), and aquafeeds (Habib, et al., 2008; Kim, et al., 2013; Velasquez, et al., 2016). Table 1 shows some of the research trials using microalgae in animal feed rations of chickens, pigs, cattle and sheep, and the resulting improvement in growth, health, fertility, and productivity.

Table 1: Effects of Microalgae Supplementation on Farm Animals (Adopted from Holman and Malau-Aduli, 2013)

\begin{tabular}{|c|c|c|c|}
\hline Species & Parameter & Summary of findings & $\begin{array}{l}\text { Selected } \\
\text { studies/Reference }\end{array}$ \\
\hline Chicken & $\begin{array}{l}\text { Growth } \\
\text { Health }\end{array}$ & $\begin{array}{l}\text { Broilers fed } 40 \mathrm{~g} / \mathrm{kg} \text { of } \\
\text { spirulina (microalgae) in } \\
\text { diet had more muscle } \\
\text { redness and yellowness } \\
\text { than the control group. } \\
\text { Increasing dietary } \\
\text { microalgae level of } 0.5 \% \text {, } \\
1 \% \text { and } 2 \% \text { of diet led to } \\
\text { increment in chicken } \\
\text { phagocytic activity. }\end{array}$ & $\begin{array}{l}\text { (A-Batshan, et al., 2001; } \\
\text { Toyomizu, et al.,2001) }\end{array}$ \\
\hline
\end{tabular}




\begin{tabular}{|c|c|c|c|}
\hline Pigs & Fertility & $\begin{array}{l}\text { Boars fed BioR from } \\
\text { microalgae at } 1.5 \mathrm{ml} / \text { day } \\
\text { had amplified ejaculate } \\
\text { volume and spermatozoa } \\
\text { mobility }\end{array}$ & (Granaci, 2007) \\
\hline Cattle & Productivity & $\begin{array}{l}\text { Saturated fatty acid levels } \\
\text { in milk decreased, } \\
\text { however, mono and } \\
\text { polyunsaturated fatty } \\
\text { acids increased when } \\
\text { crossbred Holsteins were } \\
\text { giving Spirulina at } 40 \\
\text { g/day. }\end{array}$ & (Christaki, et al., 2012) \\
\hline Sheep & Growth & $\begin{array}{l}\text { Body Condition Scores in } \\
\text { lambs was incrementally } \\
\text { higher when fed spirulina } \\
\text { levels of } 10 \% \text { and } 20 \% \\
\text { (w/w) compared to } \\
\text { controls }\end{array}$ & (Holman, et al., 2012) \\
\hline
\end{tabular}

The findings of the trial studies cited in Table 1 (above) confirms the association between microalgae supplementation in animal feeds and improved livestock performance. Making microalgae sourced feed supplement a prospective solution to the increasing nutritional requirements for animal production (Al-Batshan, et al., 2001; Toyomizu, et al., 2001; Granaci, 2007; Christaki, et al., 2012; Holman \& Malau- Aduli, 2013).

\section{Aquaculture}

According to the FAO, aquaculture can be defined as follows: "farming of aquatic organisms including fish, molluses, crustaceans and aquatic plants. Farming implies some sort of interventions in the rearing process to enhance production, such as regular stocking, feeding, protection from predators etc. Farming also implies individual or corporate ownership of the stock being cultivated" (White, et al., 2004). Hemaiswarya et al, viewed aquaculture as the cultivation of aquatic organisms such as fisheries (Hemaiswarya, et al., 2011). In aquaculture, microalgae can be used as a protein supplement in aquafeeds (Habib, et al., 2008). In 2013, Kim et al conducted a feeding trial to investigate the effects of using spirulina supplements in aquafeed, where they found that partial replacement (7.3\%) of fish meal with spirulina pacifica can replace approximately $15 \%$ aquafeed protein (26\% dietary inclusion) in fish diets (Kim, et al., 2013). In another major study, Velasquez et al (2015) demonstrated that the inclusion of 30\% Arthrospira platensis in juvenile Nile tilapia fish isonitrogenous and isolipidic diets can improve feed utilization, increase growth performance and enhance health status. Table 2 summarises some of the research areas and progress by previous studies into the use of microalgae as a nutritional supplement in aquaculture.

Table 2: Research Trial involving partial use to microalgae in Aquafeed

\begin{tabular}{|c|c|c|}
\hline Area of interest & Progress & Author(s)/Researcher(s) \\
\hline $\begin{array}{l}\text { Partial replacement of fish meal } \\
\text { (FM) with spirulina on growth } \\
\text { performance, body composition and } \\
\text { immune response of parrot fish and } \\
\text { dietary antioxidant capacity. }\end{array}$ & $\begin{array}{l}\text { Microalgae (spirulina) can } \\
\text { substitute up to } 15 \% \text { FM protein } \\
\text { ( } 26 \% \text { dietary inclusion) }\end{array}$ & (Kim, et al., 2013) \\
\hline $\begin{array}{l}\text { Effects of adding Spirulina } \\
\text { (Arthrospira platensis) in } \\
\text { experimental diets of juvenile Nile } \\
\text { tilapia. }\end{array}$ & $\begin{array}{l}30 \% \text { inclusion of Microalgae } \\
\text { (spirulina) is considered the ideal } \\
\text { level of dietary replacement for } \\
\text { increased growth performance, }\end{array}$ & (Velasquez, et al., 2016) \\
\hline
\end{tabular}




\begin{tabular}{|c|c|c|}
\hline & $\begin{array}{l}\text { improved feed utilization } \\
\text { efficiency, as well as overall } \\
\text { health status of Nile tilapia } \\
\text { juveniles. }\end{array}$ & \\
\hline $\begin{array}{l}\text { Determining the best possible level } \\
\text { of fish-oil substitution (partial or } \\
\text { complete) for maximum growth of } \\
\text { Nile tilapia using dried whole cells } \\
\text { of DHA-rich marine microalga } \\
\text { Schizochytrium sp. }(\mathrm{Sc})\end{array}$ & $\begin{array}{l}\text { It was found that "significantly } \\
\text { higher weight gain and protein } \\
\text { efficiency ratio (PER), and lower } \\
\text { (improved) feed conversion ratio } \\
\text { (FCR) and feed intake compared } \\
\text { to a control diet containing fish } \\
\text { oil (Sc0); and no significant } \\
\text { change in SGR and survival rate } \\
\text { among all diets". }\end{array}$ & (Sarker, et al., 2006) \\
\hline
\end{tabular}

\section{SWOT Analysis of Microalgae Cultivation and Livestock Agriculture in Developing Countries}

Strengths, weaknesses, opportunities and threats (SWOT) analysis is a strategic planning tool used to evaluate the strengths and weaknesses, as well as the opportunities and threats (uncertainties) involved in an industry (Pahl \& Richter, 2009) to gain information that will help develop possible (holistic) solutions to existing problems (Nouri, et al., 2008). Ommani referred to SWOT framework as a specific "basic and candid model that assesses what a business can and cannot do (based on internal capabilities), as well as its potential (external) opportunities and threats" (Ommani, 2011). The intention here is to separate information from the literatures into two groups external and internal. Once this is done, SWOT matrix is employed to identify areas in the literature that are gaps in knowledge (weaknesses or areas of improvement and uncertainties) as well as which knowledge areas are mature enough (strengths and opportunities) to be leveraged for overcoming and assisting the gaps. Based on the literature review above, the SWOT matrix in Figure 1 was created.

Opportunities \& Strengths (OS)

1. Microalgae fast growth can match the increasing demand for animal feed and animal products in developing countries (Yaakob, et al., 2014; Zhu \& Hiltunen, 2016).

2. Microalgae's ability to utilize Nitrogen, Phosphorus, and $\mathrm{CO} 2$ in waste and emits oxygen makes it environmentally friendly for livestock agriculture (Hammouda, et al, 1995; Muller-Feuga, 2000; Guedes \& Malcata, 2012; Scneider, 2006).

3. Microalgae does not require arable land for cultivation and thus sustainable for feed production without competing with food (FA0, 2009; Habib et al., 2008).

4. Microalgae is very digestible and contains proteins, carbohydrates, vitamins and minerals suitable for partial replacement or supplementation in animal feeds that can potentially reduce production cost in animal feed industries (MišurCoVá, et al., 2010; Habib, et al., 2008; Falquet \& Hurni, 1997).
Opportunities \& Weaknesses (OW)

1. Since the economy of most developing countries is improving microalgae's uncertainties such as strain selection and technological maturity can be improve through R\&D funding programmes usually found in growing nations (Abdel-Raouf, et al. 2012; Thornton, 2010; ).

2. Microalgae's cultivation for animal feeds can minimize the impacts of overgrazing and other traditional farming practices through year round harvest (Yaakob, et al., 2014; Habib et al., 2008).

\section{Threats \& Strength (TS)}

1. Air and water pollution due to animal waste can be reduced through the cultivation of microalgae in wastewater (National Research Council, 2002; Shimura \& Tabuchi, 1994).

2. Microalgae's cultivation for animal feeds can minimize the feed versus food competition for arable land and water (since alga-culture supports recycling of water(Hammouda, et al., 1995 Muller-Feuga, 2000; Guedes \& Malcata, 2012; FAO, 2009).

3. Microalgae's high nutritious content can help in the battle against malnutrition and hunger in developing countries (Yaakob, et al., 2014; Hemaiswarya, et al., 2011; Holman \& Malau-Aduli, 2013; Becker, 1994).

\section{Threats \& Weaknesses (TW)}

This quadrant highlights challenges and knowledge gaps that require further research for microalgae-livestock systems cultivation in developing countries. From the other quadrants of the SWOT matrix, its clear that the SDGs objectives intersect with potentials of integrating alga-culture with animal farming. However, from the literature the following

uncertainties/knowledge gaps need further research in order to paint a better picture of a sustainable microalgae-livestock production systems: a) Market place needs and competition

b) How the different geographical locations of developing countries affects alga-culture such as strain selection.

c) Economies of scale of cultivating algae in developing countries etc.

Figure 1: Knowledge Gaps (TW) in Microalgae-Livestock integration Literatures Based on SWOT Matrix 


\section{Conclusions}

This literature review described the role of livestock in developing countries and argued that, livestock agriculture has several linkages to the SDGs such as; clean water and sanitation $\left(\mathrm{SDG}_{6}\right)$, hunger and malnutrition $\left(\mathrm{SDG}_{2}\right)$, climate change $\left(\mathrm{SDG}_{13}\right)$, responsible consumption and production $\left(\mathrm{SDG}_{12}\right)$, and life on land $\left(\mathrm{SDG}_{15}\right)$. These linkages however, reveal that very often improving one SDG could affects the others, showing the complexity and diversity of the livestock sector. According to the literatures, livestock sustainability within the SDGs platform, depends on mitigating its impacts to public health, the environment as well as improving animal productivity to ensure food security and these requires the establishment of a groundbreaking technology(s) and sources of feed to meet the increasing demand for animal sourced products and reduce greenhouse gas (GHG) emissions. These can be done through intensifying agro-pastoral systems (such as integrated microalgae-livestock production systems). This view is also supported by the FAO who also recommends livestock-aquaculture integrated systems with algae especially in developing countries where it would be most useful to (rural) farmers already involved in livestock farming.

In view of all that has been revealed by the literatures, it is suggested that integrating microalgae with livestock systems in developing countries has the potential to solve some of the multidimensional issues of livestock agriculture sustainability and the commercialization short-comings of microalgae-based products. Moreover, the FAO suggested that animal feed enhancement should be carry out in conjunction with rest of the activities that constitute the livestock value chain (such as marketing and sales, operations, logistics etc.).This is possible through pursuing the opportunity gaps of changing customer needs, technological innovations, and market competitions by refocusing attention towards dynamic, and innovative business and marketing architecture as well as processes both internal and external to the livestock sector. Furthermore, to fully exploit the integrated microalgae-livestock farming systems a better understanding of both open and closed pond dynamics should be a prioritized by clarifying the relationship between microalgae production and animal waste (water) quality.

\section{Acknowledgements}

The authors wish to acknowledge the petroleum technology development funds (PTDF) Nigeria, for their immense support and sponsorship for the study as well as the School of Engineering, and the Built Environment, Faculty of Computing, Engineering and the Built Environment, Birmingham City University, United Kingdom for their assistance

\section{References}

Abdel-Raouf, N., Al-Homaidan, A. A., \& Ibraheem, I. M. (2012). Microalgae and wastewater treatment. Saudi Journal of Biological Sciences, 19(3), 257-275.

Adelman, I. (1984). Beyond export-led growth. World development, 12(9), 937-949.

Al-Batshan, H. A., Al-Mufarrej, S. I., Al-Homaidan, A. A., \& Qureshi, M. A. (2001). Enhancement of chicken macrophage phagocytic function and nitrite production by dietary Spirulina platensis. Immunopharmacology and immunotoxicology, 23(2), 281-289.

Aleksandrova, M., Gain, A. K., \& Giupponi, C. (2016). Assessing agricultural systems vulnerability to climate change to inform adaptation planning: an application in Khorezm, Uzbekistan. Mitigation and Adaptation Strategies for Global Change, 21(8), 1263-1287.

Barnosky, A. D. (2014). Dodging Extinction: Power, Food, Money, and the Future of Life on Earth (1st ed.). Oakland: University of California Press.

Becker, E. W. (1994). Microalgae: biotechnology and microbiology (Vol. 10). Cambridge: Cambridge University Press. 
Benemann, J. R., \& Oswald, W. J. (1996). Systems and economic analysis of microalgae ponds for conversion of $\mathrm{CO}\{\mathrm{sub} 2\}$ to biomass. Final report (No. DOE/PC/93204--T5). California Univ., Berkeley, CA (United States). Dept. of Civil Engineering.

Birthal, P. S., \& Jha, A. K. (2005). Economic losses due to various constraints in dairy production in India. Indian Journal of Animal Sciences (75), 1476-1480.

Bouwman, A. F., \& Van Der Hoek, K. W. (1997). Scenarios of animal waste production and fertilizer use and associated ammonia emission for the developing countries. Atmospheric Environment, 31(24), 4095-4102.

Britz, P. J. (1996). The suitability of selected protein sources for inclusion in formulated diets for the South African abalone. Haliotis midae. Aquaculture, 140, 63-73.

Campbell, M. N. (2008). Biodiesel: algae as a renewable source for liquid fuel. Ontario: Guelph Engineering Journal.

Cantrell, K. B., Ducey, T., \& Hunt, P. G. (2008). Livestock waste-to-bioenergy generation opportunities. Bioresource technology, 99(17), 7941-7953.

Cervantes-Godoy, D., \& Dewbre, J. (2010). Economic importance of agriculture for poverty reduction. France: OECD Food, Agriculture and Fisheries.

Chakravarty, S., Ghosh, S. K., Suresh, C. P., Dey, A. N., \& Shukla, G. (2012). Deforestation: causes, effects and control strategies. Global perspectives on sustainable forest management, 1, 1-26.

Chisti, Y. (2007). Biodiesel from microalgae. Biotechnology advances, 25(3), 294-306.

Chowdhury, S. A., Huque , K. S., \& Khatun , M. (1995). Algae in animal production. Tune Landboskole, Denmark: Agracultural Science of Biodiversity and Sustainability Workshop.

Christaki, E., Karatzia, M., Bonos,, E., Florou-Paneri, P., \& Karatzias, C. (2012). Effect of dietary Spirulina platensis on milk fatty acid profile of dairy cows. Asian Journal of Animal and Veterinary Advances, 7, 597604.

Delgado, C., Narrod, C., \& Tiongco, M. (2008). Determinants and implications of the growing scale of livestock farms in four fast-growing developing countries. Washington, D.C.: International Food Policy Research Institute. doi:10.2499/9780896291669RR157

Delgado, C., Rosegrant, M., Steinfeld, H., Ehui, S., \& Courbois, C. (1999). Livestock to 2020: the next food revolution. IFPRI Food, Agriculture, and the Environment. Washington, D.C: IFPRI.

Dethier, J. J., \& Effenberger, A. (2012). Agriculture and development: A brief review of the literature. Economic Systems, 36(2), 175-205. doi:10.1016/j.ecosys.2011.09.003

D'mello, J. F. (1992). Chemical constraints to the use of tropical legumes in animal nutrition. Animal Feed Science and Technology, 38(2-3), 237-261.

Edwards, M. (2008). Green Algae Strategy: End Oil Iimports and Engineer Sustainable Food and Fuel (1st ed.). Tempe, Arizona: TalentDNA.

Falquet, J., \& Hurni, J. P. (1997). The nutritional aspects of Spirulina. Antenna Technology.

FAO. (2002). Protein Sources for the Animal Feed Industry. Bangkok: FAO Animal Production and Health Proceedings.

FAO. (2009). The State of Food and Agriculture: Livestock in the Balance. Rome: FAO publications.

FAO. (2013). Tackling Climate Change through Livestock: A Global assessment of Emission and Mitigation Opportunities. Rome: Food and Agriculture Organization of the United Nations.

FAO. (2016). Synthesis - Livestock and the Sustainable Development Goals. Retrieved March 1, 2017, from Global Agenda for Sustainable Livestock: http://www.livestockdialogue.org/fileadmin/templates/res_livestock/docs/2016/Panama/FAO-

AGAL_synthesis_Panama_Livestock_and_SDGs.pdf

Fearnside, P. M. (2005). Deforestation in Brazilian Amazonia: history, rates, and consequences. Conservation biology, 19(3), 680-688.

Gendy, T. S., \& El-Temtamy, S. A. (2013). Commercialization potential aspects of microalgae for biofuel production: An overview. Egyptian Journal of Petroleum (22), 43-51.

Gow, H. R., Oliver, L. D., \& Gow, N. G. (2003). Value creation in farmer-driven marketing channels: the case of Murrellen pork. Journal of Food Distribution Research, 34(1), 86-91. 
Granaci, V. (2007). Achievements in the artificial insemination of swine. Animal Science and Biotechnologies, 64, 382-386.

Guedes, A. C., \& Malcata, F. X. (2012). Nutritional value and uses of microalgae in aquaculture. In Aquaculture. InTech.

Habib, M. A., Huntington, T. C., \&Hasan, M. R. (2008). A Review on Culture, Production and Use of Spirulina as Food for Humans and Feeds for Domestic Animals and Fish. Rome: Food and Agriculture Organization FAO.

Hammouda, O., Gaber, A., \& Abdel-Rao, N. (1995). Microalgae and wastewater treatment. Ecotoxicology and Environmental Safety, 31, 205-210.

Hannon, M., Gimpel, J., Tran, M., Rasala, B., \& Mayfield, S. (2010). Biofuels from algae: challenges and potential. San Diego: Future Science Ltd.

Hemaiswarya, S., Raja, R., Kumar, R. R., Ganesan, V., \& Anbazhagan, C. (2011). Microalgae: a sustainable feed source for aquaculture. World Journal of Microbiology and Biotechnology, 27(8), 1737-1746.

Herrero, M., Grace, D., Njuki, J., Johnson, N., Enahoro, D., Silvestri, S., \& Rufino, C. M. (2013). The roles of livestock in developing countries. Animal: an international journal of animal bioscience, 7(1), 3-18. doi:10. $1017 / \mathrm{S} 1751731112001954$

Holman, B. B., \& Malau-Aduli, A. O. (2013). Spirulina as a livestock supplement and animal feed. Journal of animal physiology and animal nutrition, 97(4), 615-623.

Hossain, A. S., Salleh, A., Boyce, A. N., Chowdhury, P., \& Naqiuddin, M. (2008). Biodiesel fuel production from algae as renewable energy. American journal of biochemistry and biotechnology, 4(3), 250-254.

IFAH. (2012). The Costs of Animal Disease. Oxford: Oxford Analytica.

ILRI. (2007). Markets That Work: Making a Living from Livestock. Nairobi: International Livestock Research Institute (Nairobi, Kenya).

Iqubal, M. A. (2013). Livestock Husbandry and Environmental Problems. International Journal of Scientific and Research Publication, 3(5), 1-4.

Jahnke, H. E., \& Jahnke, H. E. (1982). Livestock production systems and livestock development in tropical Africa (Vol. 35). Kiel: Kieler Wissenschaftsverlag Vauk.

Janzen, H. H. (2011). What place for livestock on a re-greening earth? Animal Feed Science and Technology, $166,783-796$.

Johnston, B. F., \& Mellor, J. W. (1961). The Role of Agriculture in Economic Development. The American Economic Review, 51(4), 566-593.

Kamuanga, M. J., Somda, J., \& Kagoné, H. (2008). Livestock and regional market in the Sahel and West Africa: Potentials and Challenges. ssy-les-Moulineaux: SWAC-OECD/ECOWAS.

Kim, S. S., Rahimnejad, S., Kim, K. W., \& Lee, K. J. (2013). Partial replacement of fish meal with Spirulina pacifica in diets for parrot fish (Oplegnathus fasciatus). Turkish Journal of Fisheries and Aquatic Sciences, 13(2), 197-204.

Kirst, G. O., \& Wiencke, C. (1995). Ecophysiology of polar algae. Journal of Phycology, 31(2), 181-199.

Kovacevic, V., \& Wesseler, J. (2010). Cost-effectiveness analysis of algae energy production in the EU. Energy Policy, 38(10), 5749-5757.

Leng, R. A., \& Fujita, T. (1997). Tree foliage in ruminant nutrition. FAO.

Mainardi, S. (1998). AN ECONOMETRIC ANALYSIS OF FACTORS AFFECTING TROPICAL AND SUBTROPICAL DEFORESTATION. Agrekon, 37(1), 23-65.

Martin, J. B., \& Madewell, C. E. (1971). Environmental and Economic Aspects of Recycling Livestock WastesAlgae Production Using Waste Products. Southern Journal of Agricultural Economics, 30(1), 137-142.

Meissner, H. H., \& Paulsmeier, D. V. (1995). Plant compositional constituents affecting between-plant and animal species prediction of forage intake. Journal of Animal Science, 73(8), 2447-2457.

Mekonnen, M. M., \& Hoekstra, A. Y. (2012). A global assessment of the water footprint of farm animal products. Ecosystems, 15(3), 401-415. 
Miao, X., \&Wu, Q. (2006). Biodiesel production from heterotrophic microalgal oil. Bioresource technology, 97(6), 841-846.

MišurCoVá, L., KráčMar, S., KLeJduS, B., \& VaCeK, J. (2010). Nitrogen content, dietary fiber, and digestibility in algal food products. Czech Journal of Food Sciences, 28(1), 27-35.

Moorhead, K., \& Cysewski, G. R. (2011). SPIRULINA: Nature's Superfood. Kailua-Kona, Hawaii: Cyanotech Corporation.

Morton, D. C., DeFries, R. S., Shimabukuro, Y. E., Anderson, L. O., Arai, E., del Bon Espirito-Santo, F., . . . Morisette, J. (2006). Cropland expansion changes deforestation dynamics in the southern Brazilian Amazon. Proceedings of the National Academy of Sciences, 103(39), 14637-14641.

Mostafa, S. S., Shalaby, E. A., \& Mahmoud, G. I. (2012). Cultivating Microalgae in Domestic Wastewater for Biodiesel Production. Notulae Scientia Biologicae, 56-65.

Muller-Feuga, A. (2000). The role of microalgae in aquaculture: situation and trend. Journal of Applied Phycology, 12, 527-534.

National Research Council. (2002). Air Emissions from Animal Feeding Operations: Current Knowledge, Future Needs. Washington D.C: The National Academies Press.

Niggli, U., Schmid, H., \& Fliessbach, A. (2008). Organic farming and climate change. Geneva: Organic Farming and Climate Change. International Trade Centre (ITC).

Nouri, J., Karbassi, A. R., \& Mirkia, S. (2008). Environmental management of coastal regions in the Caspian Sea. International Journal of Environmental Science \& Technology, 5(1), 43-52.

Okello, W. O., Muhanguzi2, D., MacLeod, E. T., Welburn, S. C., Waiswa, C., \& Shaw, A. P. (2015). Contribution of draft cattle to rural livelihoods in a district of southeastern Uganda endemic for bovine parasitic diseases: an economic evaluation. Parasites \& Vectors, 8(571), 1-9. doi:DOI 10.1186/s13071-015-1191-9

O'mara, F. P. (2011). The significance of livestock as a contributor to global greenhouse gas emissions today and in the near future. Animal Feed Science and Technology, 166, 7-15.

Ommani, A. R. (2011). Strengths, weaknesses, opportunities and threats (SWOT) analysis for farming system businesses management: Case of wheat farmers of Shadervan District, Shoushtar Township, Iran. African journal of business management, 5(22), 9448.

Orheruata, A. M., \& Omoyakhi, J. M. (2008). Livestock-Environment Interaction: Issues and options in Nigeria. Journal of Applied Sciences and Environmental Management, 12(2), 129 - 133.

Owen, E., \& Jayasuriya, M. N. (1989). Use of crop residues as animal feeds in developing countries. Research and Development in Agriculture, 6(3), 129-138.

Pahl, N., \& Richter, A. (2009). Swot Analysis. Idea, Methodology and a Practical Approach (1st ed.). Berlin: GRIN Verlag GmbH.

Paul, H., Ernsting, A., Semino, S., Gura, S., Lorch, A., EcoNexus, B., \& de Reflexion Rural, G. (2009). Agriculture and climate change: Real problems, false solutions. Bangkok: preliminary report by Econexus, Biofuelwatch, Grupo de Reflexion Rural and NOAH.

Pelletier, N., \& Tyedmers , P. (2010). Forecasting potential global environmental costs of livestock production 2000-2050. Proceedings of the National Academy of Sciences, 107(43), 18371-18374.

Phang, S. (1991). The role of Algae in Livestock-Fish Integrated farming Systems. Kuala Lumpur: FAO.

Pica-Ciamarra, U., \& Otte, J. (2009). The 'Livestock Revolution': Rhetoric and Reality. FAO. Rome: PPLPI Research Report No. 09-05.

Poppi,, D. P., \& McLennan,, S. R. (2010). Nutritional research to meet future challenges. Animal Production Science, 50, 329-338.

Radmer, R. J. (1996). Algal diversity and commercial algal products. Bioscience, 46(4), 263-270.

Sahoo, D., \& Seckbach, J. (2015). The Algae World (Cellular Origin, Life in Extreme Habitats and Astrobiology) (1st ed.). Springer.

Sansoucy, R. (1995). Livestock-a driving force for food security and sustainable development. World, 3074(5389), 1035.

Sarker, P. K., Kapuscinski, A. R., Lanois, A. J., Livesey, E. D., Bernhard, K. P., \& Coley, M. L. (2006). Towards sustainable aquafeeds: complete substitution of fish oil with marine microalga Schizochytrium sp. 
improves growth and fatty acid deposition in juvenile Nile tilapia (Oreochromis niloticus). PloS one, 11(6), 117.

Schaffnit-Chatterjee, C., Schneider, S., Peter, M., \& Mayer, T. (2011). Mitigating climate change through agriculture. Deutsche Bank Research.

Schneider, D. (2006). Grow your Own? : Would the Wide Spread Adoption of Biomass-Derived Transportation Fuels Really Help the Environment. American Scientist.

Sheehan, J., Dunahay, T., Benemann, J., \& Roessler, P. (1998). A look back at the US Department of Energy's aquatic species program: biodiesel from algae. Golden: National Renewable Energy Laboratory. doi:NREL/TP580-24190

Shimura, M., \& Tabuchi, T. (1994). The effect of livestock on the concentration of nitrogen in stream water. Water Science and Technology, 30(7), 167-170.

Simbaya, J. (2002). Potential of fodder tree/shrub legumes as a feed resource for dry season supplementation of smallholder ruminant animals. Field evaluation of animal feed supplementation packages, 69.

Singh, J., \& Gu, S. (2010). Commercialization potential of microalgae for biofuels production. Renewable and Sustainable Energy Reviews, 2596-2610.

Spolaore, P., Joannis-Cassan, C., Duran, E., \& Isambert, A. (2006). Commercial applications of microalgae. Journal of bioscience and bioengineering, 101(2), 87-96.

The World Bank. (2009). Minding the stock: bringing public policy to bear on Livestock Sector Development. Washington, DC : The International Bank for Reconstruction and Development/The World Bank. doi:Report No. 44010-GLB

The World Bank. (2012). Agriculture and Environment Services: Identifying Investment Opportunities for Ruminant Livestock Feeding in Developing Countries. Washington DC: International Bank for Reconstruction and Development / International Development Association orThe World Bank.

Thornton, P. K. (2010). Livestock production: recent trends, future prospects. Philosophical Transactions of the Royal Society B, 365, 2853-2867.

Thu, C. T., Cuong, P. H., Van Chao, N., Trach, N. X., \& Trach, S. G. (2012). Manure management practices on biogas and non-biogas pig farms in developing countries-using livestock farms in Vietnam as an example. Journal of Cleaner Production, 31(27), 64-71.

Timmer, C. P. (2002). Agriculture and economic development. Handbook of agricultural economics, 2, 1487 1546.

Toyomizu, M., Sato, K., Taroda, H., Kato, T., \& Akiba, Y. (2001). Effects of dietary Spirulina on meat colour in muscle of broiler chickens. British Poultry Science, 42(2), 197-202.

UNDP. (2015). Transforming Our World: The 2030 Agenda for Sustainable Development A/RES/70/1. United Nation. Retrieved from sustainabledevelopment.un.org

Van Kooten, G. C., \& Bulte, E. H. (2000). The economics of nature: managing biological assets. Blackwell Publishers.

Veisi, H., Khoshbakht, K., \& Sabahi, H. (2013). A participatory assessment of agro-ecosystem sustainability in Abesard, Iran. International Journal of Agricultural Sustainability, 11(1), 52-68.

Velasquez, S. F., Chan, M. A., Abisado, R. G., Traifalgar, R. M., Tayamen, M. M., Maliwat, G. F., \& RagazaEmail , J. A. (2016). Dietary Spirulina (Arthrospira platensis) replacement enhances performance of juvenile Nile tilapia (Oreochromis niloticus). Journal of Applied Phycology, 28(2), 1023-1030.

Vitti, D. S., Abdalla, A. L., Bueno, I. C., Silva Filho, J. C., Costa, C., Bueno, M. S., . . Godoy, B. P. (2005). Do all tannins have similar nutritional effects? A comparison of three Brazilian fodder legumes. Animal Feed Science and Technology, 119(3), 345-361.

Vogel, S. J. (1994). Structural changes in agriculture: production linkages and agricultural demand-led industrialization. Oxford: Oxford Economic Papers.

Wassenaar, T., Gerber, P., Verburg, P. H., Rosales, M., Ibrahim, M., \& Steinfeld, H. (2007). Projecting land use changes in the Neotropics: The geography of pasture expansion into forest. Global Environmental Change, 17(1), 86-104.

Whelan, J., Msefer, K., \& Chung, C. V. (2001). Economic supply \& demand. MIT. 
White, K., O'Neill, B., \& Tzankova, Z. (2004). At a Crossroads: Will Aquaculture Fulfill the Promise of the Blue Revolution? SeaWeb.

World Bank. (2013). Regional aggregation using 2011 PPP and \$1.9/day poverty line. PovcalNet. Retrieved February 28, 2017, from http://iresearch.worldbank.org/PovcalNet/povDuplicateWB.aspx

Yaakob, Z., Ali, E., Zainal, A., Mohamad, M., \& Takriff, M. S. (2014). An overview: biomolecules from microalgae for animal feed and aquaculture. Journal of Biological Research-Thessaloniki, 21(1), 6.

Zhu, L. D., \& Hiltunen, E. (2016). Application of livestock waste compost to cultivate microalgae for bioproducts production: A feasible framework. Renewable and Sustainable Energy Reviews, 54, 1285-1290.

Ziervogel, G., Nyong, A., Osman, B., Conde, C., Cortés, S., \& Downing, T. (2006). Climate variability and change: implications for household food security. Washington, DC: Assessment of Impacts and Adaptations to Climate Change (AIACC). 